\title{
Congenital sensorineural hearing loss- A radiological (CT and MRI) study
}

\author{
Gupta A. ${ }^{1}$, Shrivastava O. P. ${ }^{2}$ \\ ${ }^{1}$ Dr. Anuj Gupta, Assistant Professor, Government Medical College, Rajnandgaon (C.G.), ${ }^{2}$ Dr. O. P. Shrivastava, Senior \\ Medical Officer, District Hospital, Raipur, CG, India.
}

Corresponding Authors: Dr. Anuj Gupta, Dept. of ENT, Government Medical College, Rajnandgaon (C.G.). Email: justanuj@yahoo.com

\begin{abstract}
Aims: Congenital deafness refers to hearing loss which is believed to have been present since birth. The purpose of this study is to evaluate the clinical application of computed tomography (CT) and magnetic resonance imaging (MRI) in children with profound congenital deafness and to analyze anatomic abnormalities of the inner ear and the vestibulocochlear nerve. Methods: A cross-sectional and observational study was carried out in Department of ENT of a tertiary care centre, in 50 cases of congenital deafness. All cases were analyzed for detailed history and underwent clinical audiological evaluations, high resolution computed tomography (CT) and 3D magnetic resonance imaging (MRI) of bilateral temporal bones. Result: Out of total 50 patients, majority of them presented between 6 to 30 months of age. CT scan findings were found radiologically abnormal in 54\% cases. Most commonly observed abnormality $(21.82 \%$ in bilateral side) in CT scan was of middle ear cleft followed by vestibule ( $20 \%$ in bilateral side). MRI findings were found abnormal in $88 \%$ cases. Most commonly observed abnormality ( $39.51 \%$ in right side and $45.07 \%$ in left side) in MRI was of semi-circular canal followed by vestibules (16.05\% in right side and $18.31 \%$ in left side). Conclusion: All children with congenital deafness should undergo radiological investigation of the temporal bone and inner ear. The decision whether to perform a CT or MRI will depend on scanner availability and management considerations, but cochlear implant candidates will require both.
\end{abstract}

Keywords: Congenital, Sensorineural Hearing loss, Temporal bone, Tomography, Magnetic resonance imaging.

\section{Introduction}

Congenital sensorineural hearing loss is one of the most common birth defects with incidence of approximately 1:1000 live births [1]. Most inner ear malformations arise when formation of the membranous labyrinth is interrupted during the first trimester of pregnancy [2]. This may be due to inborn genetic error or as a result of teratogenic exposure during the period of inner ear organogenesis between the fourth and eighth week of gestation.

Radiology plays an important role for the management of congenital deafness and especially in cases where cochlear implant has been considered as the treatment for the sensorineural deafness. Radiology gives information about the type of malformation, additional pathologies in the middle ear and mastoid, and the presence or absence of the vestibulocochlear nerve.

Manuscript received: $25^{\text {th }}$ July 2018

Reviewed: $4^{\text {th }}$ August 2018

Author Corrected: $9^{\text {th }}$ August 2018

Accepted for Publication: $13^{\text {th }}$ August 2018
Both high resolution computed tomography scan (HRCT) of the temporal bone and magnetic resonance imaging scan (MRI) of the inner ear are used in radiography of congenital sensorineural hearing loss.

HRCT and MRI of the temporal bone provide different, but complementary information [3].

The HRCT is excellent for demonstrating details of the temporal bone, mastoid pneumatization, and cochlear patency $[4,5,6]$. CT is inadequate for visualizing inner ear neural structures, fluid or fibrosis $[3,6]$.

MRI is superior to CT in demonstrating inner auditory canal nerves, retrocochlear diseases and membranous alterations of the inner ear; it fails to provide information about bone structures, and is more costly $[3,5,6]$. 


\section{Aims and objectives}

1. To access the value of Computed tomography (CT) and Magnetic resonance imaging (MRI) of temporal bones in the evaluation of children with congenital deafness.

2. To analyze anatomic abnormalities of the inner ear and the vestibulocochlear nerve in children with congenital sensorineural hearing loss.

\section{Materials and methods}

The study was carried out in the Department of ENT of a tertiary care centre during the period of October 2009 to October 2011 on 50 patients.

Inclusion Criteria: The cases were selected randomly among the patients who attended ENT department for hearing impairment and under or delayed development of speech and language since birth.

\section{Exclusion Criteria}

1. Subjects having normal or near normal level of hearing before developing total or severe sensory neural hearing loss.

2. Subjects having sensory neural hearing loss of less than $70 \mathrm{~dB}$ bilaterally.

The protocol followed for examination of subjects includes careful and detailed history regarding information on age, sex, religion, parent's occupation and literacy along with antenatal, intranatal, postnatal history, developmental and family history using a standard questionnaire, prepared for this study. Examination of patient includes general physical and systemic examination, ear, nose, throat examination and psychologist consultation.

Clinical audiological evaluations include Pure Tone Audiometry, Impedance audiometry, Brain stem Evoked Response Audiometry, and Oto-acoustic Emission to determine the type and degree of hearing loss. Radiological assessments are done by High resolution Computed Tomography (CT) of bilateral temporal bones and 3D Magnetic resonance imaging (MRI) of bilateral petrous temporal bones.
High resolution Computed Tomography (CT) of the temporal bone of all cases was taken in both axial and coronal section. In all cases $0.6 \mathrm{~mm}$ thickness contiguous axial sections in bony algorithm with $1 \mathrm{~mm}$ thickness contiguous axial and coronal reformations. The following observations were made: (a) External auditory canals, (b) Middle ear clefts, (c) Middle ear ossicles, (d) Mastoid antrum and mastoid air cells, (e) Facial nerve canals, (f) Bilateral jugular bulbs, (g) Carotid canals, (h) Cochlea, (i) Modioli, (j) Semicircular canals, (k) Vestibules, (l) Vestibular aqueducts, (m) Internal auditory meatus, (n) CP angle cisterns.

3D Magnetic resonance imaging (MRI) of membranous labyrinth and internal acoustic meatus covering bilateral petrous temporal bones of all cases in axial and coronal planes was taken. $0.8 \mathrm{~mm}$ thickness 3D-FIESTA sequences covering bilateral petrous temporal bones in axial and coronal planes and $0.8 \mathrm{~mm}$ thickness contiguous axial and coronal reformations were recorded with 3D-VR reformation of membranous labyrinth. The following observations were made: (a) Cochlea, (b) Modioli, (c) Semicircular canals, (d) Vestibule, (e) Vestibular aqueducts, (f) Endolymphatic sacs, (g) Internal acoustic meatus, (h) Facial nerve, (i) Vestibular division of auditory nerve, (j) Cochlear division of auditory nerve.

The observations were analyzed and classified in tables; statistical analysis was done on observations of Computed Tomography (CT) and Magnetic Resonance (MRI).

Method of statistical analysis: All statistical analysis was conducted using the SPSS v.10.0 statistical software package (SPSS Corporation, Chicago, IL). For the analysis of categorical measures, a series of ChiSquare $(\chi 2)$ test were conducted. This test is used to test a distribution observed in the field against another distribution determined by a null hypothesis.

The findings of radiological study were analysed by Chi-Square $(\chi 2)$ to know the significance value. Level of significance used in calculation was 0.05 .

\section{Observation and result}

A total of 50 patients presenting with hearing impairment and/or under or delayed development of speech and were included in this study. The age of patients ranged between 1 year and 18 years. Total numbers of males were 23 (46\%) and females were 27 (54\%) with Male: Female ratio was 1:1.17. Maximum patients (36\%) were in age group of 2-4 years. 
Audiological evaluation: Audiological evaluation is done by pure tone audiometry (in cooperative patients), impedance audiometry, otoacoustic emission (OAE) and brainstem evoked response audiometry (BERA). Otoacoustic emission was absent in 48 cases in bilateral ears and present in remaining 2 casesin bilateral ears. In all 50 cases of congenital deafness, Brainstem evoked response audiometry showed absent wave V.

Radiological evaluation:

Observation of Computed tomography scans (CT) of patients: All the 50 cases with congenital deafness that underwent a CT scan, showed abnormality in 54\% cases (Table No. I). However, no significant difference was observed in CT findings in children with congenital deafness by chi square analysis $(\mathrm{df}=1)$. The most commonly observed abnormality detected by CT scan $(21.82 \%$ in bilateral side) was of middle ear cleft (statistically significant at $\mathrm{p}<0.05)$. Out of these abnormalities of middle ear cleft in CT scan, most common was small bony bar (10\% in bilateral ears) followed by soft tissue density (6\% in right ear and $8 \%$ in left ear). Second most common abnormality observed in CT scan was of vestibules ( $20 \%$ in bilateral sides). Most commonly observed abnormality of vestibule in CT scan was mild dilatation ( $10 \%$ in bilateral ears) followed by enlarged vestibule ( $4 \%$ in bilateral ears). Third most common abnormality observed in CT scan was of mastoid antrum and mastoid air cells (14.55\% in right side and $16.36 \%$ in left side). Out of these abnormalities of antrum in CT scan, most common was soft tissue opacification (6\% in right ear and $8 \%$ in left ear) followed by hypopneumatization ( $4 \%$ in bilateral ears).

Table No.-I: Ear abnormalities detected by computed tomography (CT) scans.

\begin{tabular}{|c|c|c|c|c|}
\hline \multirow{2}{*}{ S.No. } & Structures & \multicolumn{3}{|c|}{ Abnormal } \\
\cline { 2 - 4 } & & Right & Left & Total \\
\hline 1 & External auditory canal & $5(9.09 \%)$ & $5(9.09 \%)$ & $10(9.09 \%)$ \\
\hline 2 & Middle ear cleft & $12(21.82 \%)$ & $12(21.82 \%)$ & $24(21.82 \%)$ \\
\hline 3 & Middle ear ossicles & 0 & $1(1.82 \%)$ & $1(0.91 \%)$ \\
\hline 4 & Mastoid antrum and mastoid air cells & $8(14.55 \%)$ & $9(16.36 \%)$ & $17(15.46 \%)$ \\
\hline 5 & B/L jugular bulb & $1(1.82 \%)$ & $1(1.82 \%)$ & $2(1.82 \%)$ \\
\hline 6 & Cochlea & $2(3.64 \%)$ & $2(3.64 \%)$ & $4(3.64 \%)$ \\
\hline 7 & Modioli & $3(5.46 \%)$ & $2(3.64 \%)$ & $5(4.55 \%)$ \\
\hline 8 & Semicircular canal & $4(7.27 \%)$ & $4(7.27 \%)$ & $8(7.27 \%)$ \\
\hline 9 & Vestibules & $11(20 \%)$ & $11(20 \%)$ & $22(20 \%)$ \\
\hline 10 & Vestibular aqueduct & $3(5.46 \%)$ & $3(5.46 \%)$ & $6(5.46 \%)$ \\
\hline 11 & Internal auditory meatus & $6(10.91 \%)$ & $5(9.09 \%)$ & $11(10 \%)$ \\
\hline
\end{tabular}

$* \chi 2(\mathrm{df}=10)=61.6($ Significant at $\mathrm{p}<0.05)$

Abnormal external auditory canal in CT scan was observed in $10 \%$ cases in bilateral ears. Most commonly observed abnormality of external auditory canal in CT scan was soft tissue density (4\% in right ear and $6 \%$ in left ear) followed by soft tissue plug (4\% in right ear and $2 \%$ in left ear). Abnormal middle ear ossicles in CT scan were observed in $2 \%$ cases in right ear and $4 \%$ cases in left ear. In one case partial incudo-malleolar fusion was observed in bilateral ear and in one case enhancement of ossicles was observed in left ear. Abnormal jugular bulb (mild high riding jugular bulb) in CT scan was observed in $2 \%$ cases in bilateral ears.

Abnormal cochlea in CT scan was observed in $4 \%$ cases in bilateral ears. In one case (2\%) enlarged cochlea was observed in bilateral ears and in one case $(2 \%)$ fusion of middle and apical turns cochlea (Mondini Deformity) was observed in bilateral ears (Figure 1). Abnormal modiolus in CT scan was observed in $8 \%$ cases in right ear and $6 \%$ cases in left ear. In one case attenuated modiolus was observed in right ear while in one case malformed modioli were observed in bilateral ears. Abnormal semicircular canals in CT scan were observed in $8 \%$ cases in right ear and $10 \%$ cases in left 
ear. Most commonly observed abnormality of semicircular canal in CT scan was dysplasia (4\% in bilateral ears) and enlarged semicircular canal (4\%) in bilateral ears. Abnormal vestibular aqueduct in CT scan was observed in 6\% cases in bilateral ears. Most commonly observed abnormality of vestibular aqueduct in CT scan was mild dilatation (4\%) in bilateral ears. Abnormal internal auditory meatus in CT scan was observed in $14 \%$ cases in right ear and $12 \%$ cases in left ear. Most commonly observed abnormality of internal auditory meatus in CT scan was enlarged internal auditory meatus (6\% in bilateral ears).

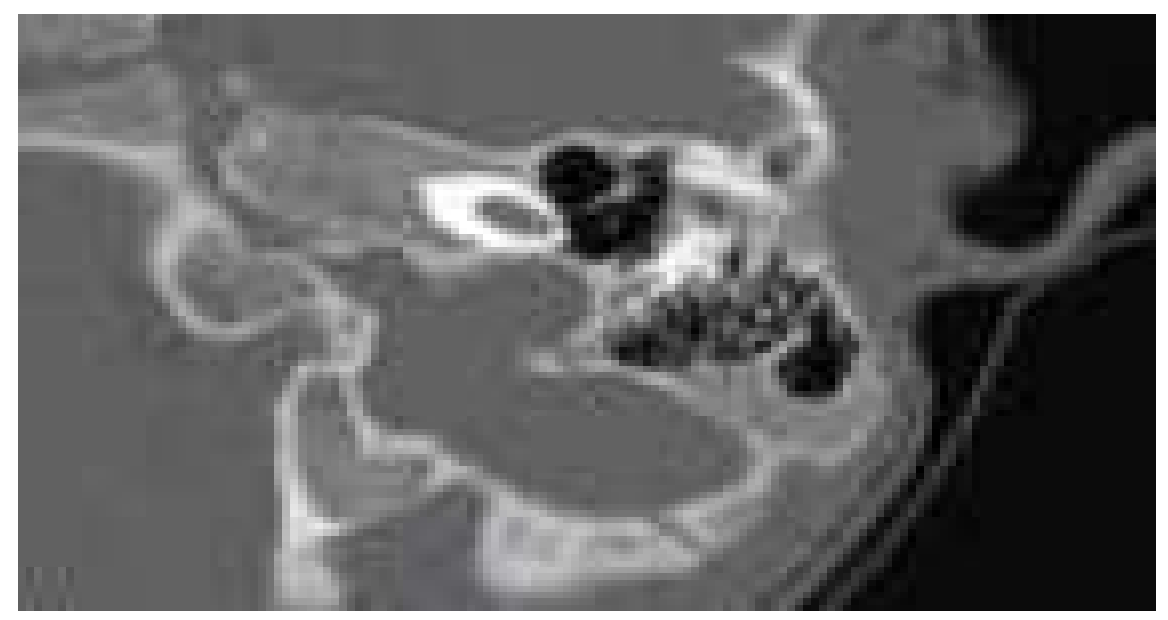

Figure-1: HRCT scan of left temporal bone with axial section showing Mondini Deformity

Observation of Magnetic resonance imaging (MRI) of patients: MRI was done in all patients and MRI findings were found abnormal in $88 \%$ cases (statistically significant at $\mathrm{p}<0.05$ ). Total 152 abnormalities were detected in 100 ears of 50 patients of congenital deafness by MRI ( 81 abnormalities in right ear and 71 abnormalities in left ear), with a majority of patients demonstrating multiple abnormalities (Table No. II). Most commonly observed abnormality (39.51\% in right side and $45.07 \%$ in left side) was of semicircular canal (statistically significant at $p<0.05$ ). Out of these abnormalities of semicircular canal in MRI, most common was stenosis (50\% cases in right ear and $46 \%$ cases in left ear) followed by atresia or non-visualisation (6\% in right ear and $10 \%$ in left ear) and dysplastic semicircular canal (8\% in right ear and $6 \%$ in left ear). Second most common abnormality observed in MRI was of vestibules (16.05\% in right side and $18.31 \%$ in left side). Out of these abnormalities of vestibule, most common was dilatation or enlargement ( $24 \%$ cases in bilateral ears).

Table No.-II: Ear abnormalities detected by magnetic resonance imaging (MRI).

\begin{tabular}{|c|c|c|c|c|}
\hline \multirow{2}{*}{ S.No. } & \multirow{2}{*}{ Structures } & \multicolumn{3}{|c|}{ Abnormal } \\
\cline { 3 - 5 } & & Right & Left & Total \\
\hline 1 & Cochlea & $5(6.17 \%)$ & $5(7.04 \%)$ & $10(6.58 \%)$ \\
\hline 2 & Modioli & $4(4.94 \%)$ & $2(2.82 \%)$ & $6(3.95 \%)$ \\
\hline 3 & Semicircular canal & $32(39.51 \%)$ & $32(45.07 \%)$ & $64(42.11 \%)^{*}$ \\
\hline 4 & Vestibule & $13(16.05 \%)$ & $13(18.31 \%)$ & $26(17.11 \%)$ \\
\hline 5 & Vestibular aqueduct & $4(4.94 \%)$ & $4(5.63 \%)$ & $8(5.26 \%)$ \\
\hline 6 & Endolymphatic sac & $3(3.7 \%)$ & $3(4.22 \%)$ & $6(3.95 \%)$ \\
\hline 7 & Internal auditory meatus & $7(8.64 \%)$ & $6(8.45 \%)$ & $13(8.55 \%)$ \\
\hline 8 & Facial nerve & $8(9.88 \%)$ & 0 & $8(5.26 \%)$ \\
\hline 9 & Cochlear division of auditory nerve & $5(6.17 \%)$ & $6(8.45 \%)$ & $11(7.24 \%)$ \\
\hline
\end{tabular}

$* \chi 2(\mathrm{df}=8)=165.48($ Significant at $\mathrm{p}<0.05)$ 
Abnormal cochlea in MRI was observed in $8 \%$ cases in bilateral ears. Mondini Deformity and its variant were observed in total 5 ears (5\%). Abnormal modioli in MRI were observed in $10 \%$ cases in right ear and $6 \%$ cases in left ear. Most commonly observed abnormality of modioli in MRI was dysplasia (4\%) in bilateral ears followed by attenuated modioli (4\% cases in right ear). Abnormal vestibular aqueduct (dilatation or enlargement) in MRI was observed in $8 \%$ cases in bilateral ears (Figure 2).

Abnormal endolymphatic sac (dilatation or enlargement) in MRI was observed in $6 \%$ cases in bilateral ears. Abnormal internal auditory meatus in MRI was observed in $16 \%$ cases in right ear and $12 \%$ cases in left ear. Most commonly observed abnormality of internal auditory meatus in MRI was enlargement (6\% cases in bilateral ears) followed by protrusion of loop of AICA (4\% in right ear and 6\% in left ear) and narrowed internal auditory meatus (4\% in right ear and $2 \%$ in left ear). Abnormal facial nerve (hypoplasia) in MRI was observed in $2 \%$ cases in right ear. Abnormal cochlear division of auditory nerve in MRI was observed in 12\% cases in right ear and $14 \%$ cases in left ear. Most commonly observed abnormality of cochlear division of auditory nerve in MRI was hypoplasia (10\% in right ear and $12 \%$ in left ear).

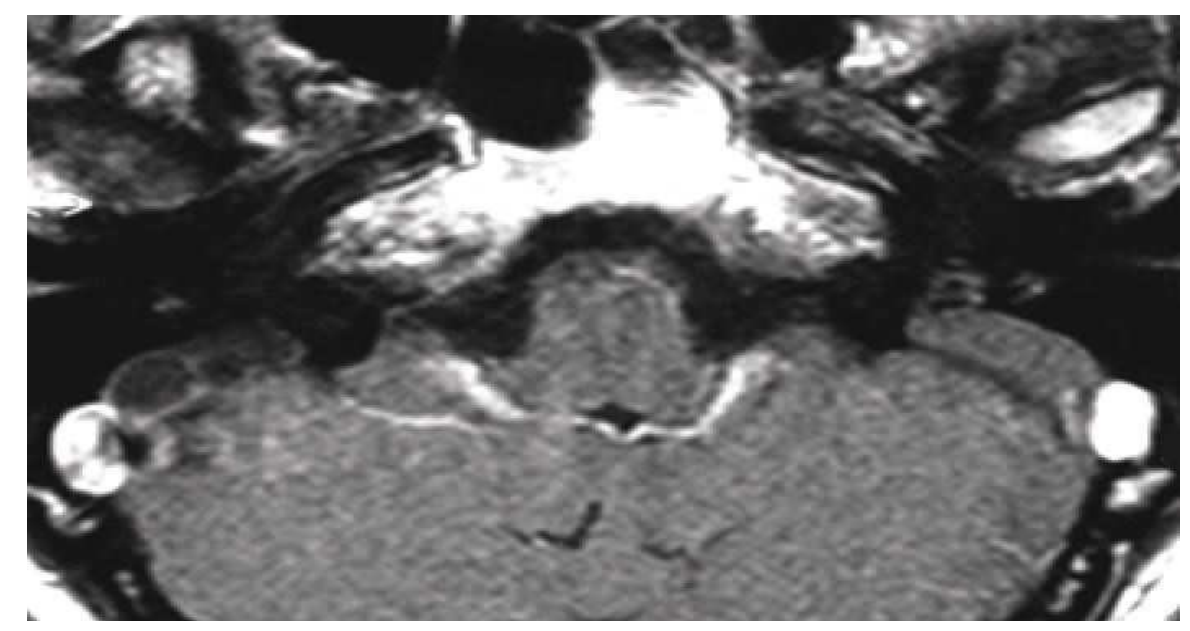

Figure-2: MRI scan of inner ear with axial section showing bilaterally enlarged vestibular aqueduct

\section{Discussion}

The purpose of this study was to access the value of computed tomography (CT) and magnetic resonance imaging (MRI) in the evaluation of inner ear abnormalities in children with congenital deafness and delayed development of speech and language and to analyze anatomic abnormalities of the inner ear and the vestibulocochlear nerve. Radiology plays an important role for the management of congenital deafness and especially in cases where cochlear implant has been planned as the treatment for the sensorineural deafness.

In present study, out of 50 cases of congenital deafness, CT scan was done in all patients. CT scan findings were found abnormal in 54\% cases. Woolford et al(1995)in their study on pre-cochlear implant children found an abnormal CT scan in $29.5 \%$ of cases [7]. Bamiouet al (2000), in a retrospective study of 116 children with bilateral sensorineural hearing loss examined the yield of computed tomography (CT) of the temporal bones. They observed abnormal CT scans in $28.4 \%$ cases [8]. Shusterman et al (1992) however, reported a yield of $12.85 \%$ abnormal CT findings in children with sensorineural hearing [9]. This wide range of CT yields may be explained partly by the improvement of imaging techniques and better understanding of SNHL related inner ear abnormalities over the years, as well as by the different populations targeted by the different studies.

In present study, out of 50 cases of congenital deafness, total 110 abnormalities were detected in 100 ears of 50 patients of congenital deafness by CT scan (55 abnormalities in each ear), with a majority of patients demonstrating multiple abnormalities. The most commonly observed abnormality ( $21.82 \%$ in bilateral side) was of middle ear cleft (statistically significant at $\mathrm{p}<0.05$ ) followed by abnormality of vestibules ( $20 \%$ in bilateral sides) and mastoid antrum and mastoid air cells (14.55\% in right side and $16.36 \%$ in left side). Comparison of CT scan findings of present study and previous studies are tabulated in Table No. III. 
Table No.- III: Comparison of CT scan findings of present study and previous studies.

\begin{tabular}{|c|c|c|c|c|c|c|c|c|c|c|c|}
\hline $\begin{array}{c}\text { CT } \\
\text { finding }\end{array}$ & EAC & $\begin{array}{c}\text { Middle } \\
\text { ear cleft }\end{array}$ & $\begin{array}{c}\text { Middle ear } \\
\text { ossicles }\end{array}$ & $\begin{array}{c}\text { Mastoid } \\
\text { antrum }\end{array}$ & $\begin{array}{c}\text { Jugul } \\
\text { ar } \\
\text { bulb }\end{array}$ & Cochlea & Modioli & SSC & Vestibule & $\begin{array}{l}\text { Vestibular } \\
\text { aquaduct }\end{array}$ & IAM \\
\hline $\begin{array}{c}\text { Jackleret } \\
\text { al (1987) } \\
{[2]}\end{array}$ & - & - & - & - & - & $\begin{array}{c}\text { Mondini } \\
\text { Dysplasia } \\
(41 \%)\end{array}$ & - & - & - & - & - \\
\hline $\begin{array}{c}\text { Bamiou } \\
\text { et al } \\
(2000) \\
{[8]}\end{array}$ & - & - & - & - & - & $\begin{array}{c}\text { Mondini } \\
\text { Dysplasia } \\
(6.03 \%)\end{array}$ & - & Abnormal (7.7\%) & - & $\begin{array}{l}\text { Dilatatio } \\
\mathrm{n}(8.6 \%)\end{array}$ & Narrowing $(2.6 \%)$ \\
\hline $\begin{array}{c}\text { Kalsotra } \\
\text { et al } \\
(2002) \\
{[10]}\end{array}$ & $\begin{array}{c}\text { Malfor } \\
\text { med } \\
(8.5 \%) \\
\text { EAC } \\
\text { Atresia } \\
(7.28 \%)\end{array}$ & - & $\begin{array}{l}\text { Isolated } \\
\text { congenital } \\
\text { middle ear } \\
\text { pathology } \\
(1.15 \%)\end{array}$ & - & - & - & - & - & - & - & - \\
\hline $\begin{array}{l}\text { Present } \\
\text { study } \\
(2011)\end{array}$ & $\begin{array}{l}\text { Abnorm } \\
\text { al }(10 \%)\end{array}$ & $\begin{array}{c}\text { Most } \\
\text { common } \\
(21.82 \%)\end{array}$ & $\begin{array}{l}\text { Abnormal (2\% } \\
\text { cases in right } \\
\text { ear and } 4 \% \\
\text { cases in left ear) }\end{array}$ & $\begin{array}{c}\text { Abnormal } \\
\text { (14.55\% in right } \\
\text { side and } 16.36 \% \\
\text { in left side) }\end{array}$ & $\begin{array}{c}\text { Mild } \\
\text { high } \\
\text { riding } \\
(2 \%)\end{array}$ & $\begin{array}{c}\text { Mondini } \\
\text { Dysplasia } \\
(2 \%)\end{array}$ & $\begin{array}{c}\text { Abnormal }(8 \% \\
\text { cases in right ear } \\
\text { and } 6 \% \text { cases in } \\
\text { left ear) }\end{array}$ & $\begin{array}{c}\text { Abnormal }(8 \% \\
\text { cases in right ear } \\
\text { and } 10 \% \text { cases in } \\
\text { left ear })\end{array}$ & $\begin{array}{c}\text { Abnormal } \\
(20 \% \text { in } \\
\text { bilateral } \\
\text { sides })\end{array}$ & $\begin{array}{c}\text { Dilatatio } \\
\mathrm{n}(4 \%) \\
\text { Enlarged } \\
(2 \%)\end{array}$ & $\begin{array}{c}\text { Abnormal ( } 14 \% \\
\text { cases in right ear } \\
\text { and } 12 \% \text { cases in } \\
\text { left ear) } \\
\text { Narrowing }(2 \%)\end{array}$ \\
\hline
\end{tabular}

(EAC- External auditory canal, SSC- Semicircular canal, IAM- Internal auditory meatus)

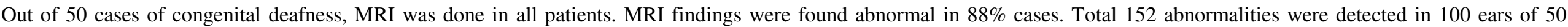
patients of congenital deafness by MRI ( 81 abnormalities in right ear and 71 abnormalities in left ear), with majorityof patients demonstrating multiple abnormalities.

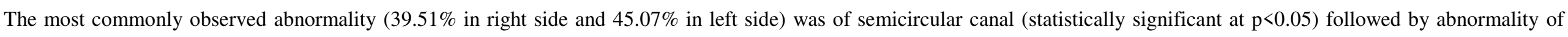

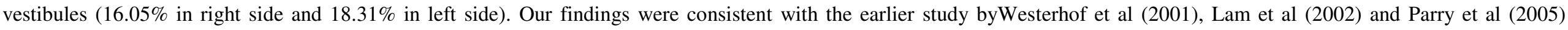
$[11,12,13]$. Comparison of MRI findings of present study and previous studies are tabulated in Table No. IV. 
Table No.-IV: Comparison of MRI findings of present study and previous studies.

\begin{tabular}{|c|c|c|c|c|c|c|c|c|c|}
\hline MRI finding & Cochlea & Modioli & SSC & Vestibule & $\begin{array}{l}\text { Vestibular } \\
\text { Aquaduct }\end{array}$ & ELS & IAM & VII Nv & $\begin{array}{l}\text { VIII Nv } \\
\text { (Co. Div.) }\end{array}$ \\
\hline $\begin{array}{c}\text { Westerhof et al } \\
\text { (2001) [11] }\end{array}$ & $\begin{array}{c}\text { Mondini } \\
\text { Abnormalities } \\
(28.5 \%)\end{array}$ & - & $\begin{array}{l}\text { Fusion of SCC } \\
\text { with Vestibule } \\
\quad(28.57 \%)\end{array}$ & - & - & - & - & - & - \\
\hline $\begin{array}{c}\text { Lam et al (2002) } \\
{[12]}\end{array}$ & $\begin{array}{c}\text { Mondini } \\
\text { Abnormalities } \\
(19.7 \%)\end{array}$ & - & - & - & $\begin{array}{c}\text { Enlargement } \\
(6.9 \%)\end{array}$ & - & Enlargement (4.2\%) & - & - \\
\hline $\begin{array}{c}\text { Parry } \\
\text { et } \operatorname{al}(2005)[13]\end{array}$ & - & - & - & $\begin{array}{c}\text { Abnormal } \\
\text { Vestibule }(23 \%)\end{array}$ & - & - & Abnormalities (16\%) & - & $\begin{array}{c}\text { Abnormalities } \\
(12 \%)\end{array}$ \\
\hline $\begin{array}{l}\text { Present study } \\
\text { (2011) }\end{array}$ & $\begin{array}{c}\text { Mondini } \\
\text { Abnormalities } \\
(5 \%)\end{array}$ & $\begin{array}{c}\text { Abnormal }(10 \% \\
\text { cases in right ear } \\
\text { and } 6 \% \text { cases in } \\
\text { left ear })\end{array}$ & $\begin{array}{c}\text { Abnormal } \\
\text { (39.51\% in right } \\
\text { side and } 45.07 \% \\
\text { in left side) }\end{array}$ & $\begin{array}{c}\text { Abnormal } \\
\text { (16.05\% in right } \\
\text { side and } 18.31 \% \\
\text { in left side) }\end{array}$ & Dilated $(8 \%)$ & $\begin{array}{c}\text { Dilated } \\
(6 \%)\end{array}$ & $\begin{array}{c}\text { Abnormal ( } 16 \% \text { cases in } \\
\text { right ear and } 12 \% \text { cases in } \\
\text { left ear) } \\
\text { Enlargement }(6 \%)\end{array}$ & $\begin{array}{l}\text { Hypoplas } \\
\text { ia }(1 \%)\end{array}$ & $\begin{array}{c}\text { Hypoplasia } \\
(11 \%) \\
\text { Aplasia }(2 \%)\end{array}$ \\
\hline
\end{tabular}

(SSC- Semicircular canal, ELS- Endolymphatic sac, IAM- Internal auditory meatus, VII Nv- Facial nerve, VIII Nv (Co. Div.)- Cochlear division of auditory nerve)

\section{Conclusion}

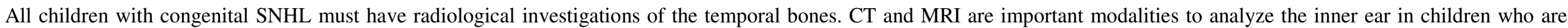

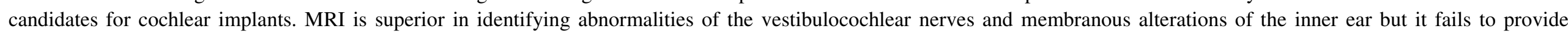
information about bone structures and is more costly.

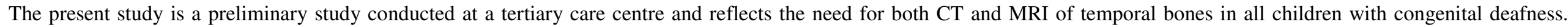

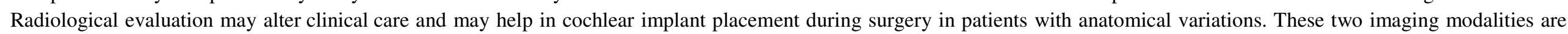
complementary to each other in detailed analysis of abnormalities of the inner ear.

Funding: Nil, Conflict of interest: Nil

Permission from IRB: Yes 


\section{References}

1. St. Martin MB, Hirsch BE. Imaging of hearing loss. Otolaryngologic Clinics of North America; 2008; Feb; 41(1):157-178.doi: 10.1016/j.otc.2007.10.007.

2. Jackler RK, Luxford WM, House WF. Congenital Malformations of the inner ear: a classification based on embryogenesis. Laryngoscope; 1987; Mar; 97(3 Pt 2 Suppl 40):2-14.

3. Gleeson TG, Lacy PD, Bresnihan M, Gaffney R, Brennan P, Viani L. High resolution computed tomography and magnetic resonance imaging the preoperative assessment of cochlear implant patients. J LaryngolOtol; 2003; 117 (9):692-95.doi: 10.1258/00222 1503322334495.

4. Lo WWM. Imaging of Cochlear and Auditory Brain Stem Implantation. Am J Neuroradiol; 1998; June-July; 19 (6): 1147-54.

5. Abdullah A, Mahmud MR, Maimunah A, Zulfiqar MA, Saim L, Mazlan R. Preoperative High Resolution $\mathrm{CT}$ and MR Imaging in Cochlear Implantation. Ann Acad Med Singapore; 2004; July; 32(4):442-5

6. Bath AP, O’DonoghueGM, Holland IM, Gibbin KP. Paediatric cochlear implantation: how reliable is computed tomography in assessing cochlear patency? Clinical Otolaryngol Allied Sciences; 1993; Dec;18(6): 475-9.

7. Woolford TJ, Roberts GR, Hartley C, Ramsden RT. Etiology of hearing loss and cochlear computed tomography: findings in preimplant assessment. Ann Otol Rhinol Laryngol Suppl. 1995; Sep; 166:201-6.
8. BamiouDE, Phelps P, Sirimanna T. Temporal bone computed tomography findings inbilateral sensorineural hearing loss. Arch Dis Child; 2000; Mar; 82(3): 257-260.

9. Shusterman D, Handler SD, Marsh RR, Bilaniuk L, Tom LWC. Usefulness of computed tomographic scan in the evaluation of sensorineural hearing loss in children. Arch Otolaryngol Head Neck Surg; 1992; May; 118(5):501-3.

10. Kalsotra P, Kumar S, Gosh P, Mishra NK, Verma IC. A Study of Congenital and Early Acquired Impairment of Hearing. JK Science: Journal of Medical Education \& Research; 2002; July-Sept; 4 (3), 136-143.

11. Westerhof JP, Rademaker J, Weber BP, Becker H. Congenital malformations of the inner ear and the vestibulocochlear nerve in children with sensorineural hearing loss: evaluation with CT and MRI. J Comput Assist Tomogr; 2001; Sep-Oct;25(5):719-26.

12. Lam WW, Hui Y, Au DK, Chow LC, Chan FL, Yu L, Wei WI. Radiological study of temporal bone in children with profound deafness before cochlear implant: CT vs magnetic resonance imaging. Zhonghua Er Bi Yan Hou Ke Za Zhi, 2002; Dec;37 (6): 440-2.

13. Parry DA, Booth T, Roland PS. Advantages of magnetic resonance imaging over computed tomography in preoperative evaluation of pediatric cochlear implant candidates. OtolNeurotol; 2005; Sep; 26 (5): 976-82.

\section{How to cite this article?}

Gupta A, Shrivastava O. P. Congenital sensorineural hearing loss- A radiological (CT and MRI) study. Trop J Ophthalmol Otolaryngol.2018;3(3):13-20.doi: 10.17511/jooo.2018.i03.02 